2012s-20

\title{
Inflation and Growth: A New Keynesian Perspective
}

Robert Amano, Tom Carter, Kevin Moran

\begin{tabular}{c}
\hline Série Scientifique \\
Scientific Series
\end{tabular}

\section{Montréal \\ Juillet 2012}

(C) 2012 Robert Amano, Tom Carter, Kevin Moran. Tous droits réservés. All rights reserved. Reproduction partielle permise avec citation du document source, incluant la notice (C).

Short sections may be quoted without explicit permission, if full credit, including (C) notice, is given to the source.
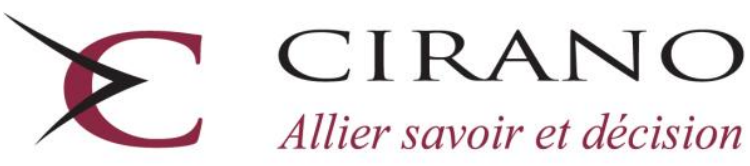

Allier savoir et décision

Centre interuniversitaire de recherche en analyse des organisations 


\section{CIRANO}

Le CIRANO est un organisme sans but lucratif constitué en vertu de la Loi des compagnies du Québec. Le financement de son infrastructure et de ses activités de recherche provient des cotisations de ses organisations-membres, d'une subvention d'infrastructure du Ministère du Développement économique et régional et de la Recherche, de même que des subventions et mandats obtenus par ses équipes de recherche.

CIRANO is a private non-profit organization incorporated under the Québec Companies Act. Its infrastructure and research activities are funded through fees paid by member organizations, an infrastructure grant from the Ministère du Développement économique et régional et de la Recherche, and grants and research mandates obtained by its research teams.

\section{Les partenaires du CIRANO}

\section{Partenaire majeur}

Ministère du Développement économique, de l'Innovation et de l'Exportation

\section{Partenaires corporatifs}

Autorité des marchés financiers

Banque de développement du Canada

Banque du Canada

Banque Laurentienne du Canada

Banque Nationale du Canada

Banque Royale du Canada

Banque Scotia

Bell Canada

BMO Groupe financier

Caisse de dépôt et placement du Québec

Fédération des caisses Desjardins du Québec

Financière Sun Life, Québec

Gaz Métro

Hydro-Québec

Industrie Canada

Investissements PSP

Ministère des Finances du Québec

Power Corporation du Canada

Rio Tinto Alcan

State Street Global Advisors

Transat A.T.

Ville de Montréal

\section{Partenaires universitaires}

École Polytechnique de Montréal

HEC Montréal

McGill University

Université Concordia

Université de Montréal

Université de Sherbrooke

Université du Québec

Université du Québec à Montréal

Université Laval

Le CIRANO collabore avec de nombreux centres et chaires de recherche universitaires dont on peut consulter la liste sur son site web.

Les cahiers de la série scientifique (CS) visent à rendre accessibles des résultats de recherche effectuée au CIRANO afin de susciter échanges et commentaires. Ces cahiers sont écrits dans le style des publications scientifiques. Les idées et les opinions émises sont sous l'unique responsabilité des auteurs et ne représentent pas nécessairement les positions du CIRANO ou de ses partenaires.

This paper presents research carried out at CIRANO and aims at encouraging discussion and comment. The observations and viewpoints expressed are the sole responsibility of the authors. They do not necessarily represent positions of CIRANO or its partners. 


\title{
Inflation and Growth: A New Keynesian Perspective*
}

\author{
Robert Amano ${ }^{\dagger}$, Tom Carter ${ }^{*}$, Kevin Moran ${ }^{\S}$
}

\section{Résumé / Abstract}

The long-run relation between growth and inflation has not yet been studied in the context of nominal price and wage rigidities, despite the fact that these rigidities now figure prominently in workhorse macroeconomic models. We therefore integrate staggered price- and wage-setting into an endogenous growth framework. In this setting, growth and inflation are linked via the incentive to innovate. For standard calibrations, the linkage is strong: as trend inflation shifts from -5 to 5 percent, the range over which the economy's steady-state growth rate varies spans 50 basis points, implying up to a 15 percent output differential after thirty years. Nominal wage rigidity plays a critical role in generating these results, and compounding of inflation's growth effects implies large welfare losses. Endogenous growth thus proves a key channel via which inflation impacts New Keynesian economies.

Mots-clés/Keywords : non-superneutrality, endogenous growth, welfare costs of inflation

Codes JEL : E31, E52, O31, O42

\footnotetext{
* We thank Guido Ascari, Mike Dotsey, Jordi Gali and Victor Rios-Rull for their comments and suggestions. We are also grateful for useful discussions with our colleagues and seminar participants at the Bank of Canada and Centre de Recerca en Economia Internacional; the Universitat Pompeu Fabra workshop on New Perspectives on Monetary Policy Design; the Midwestern Macro Meetings at Indiana University; the CEA annual conference in Toronto; the Far East and South Asia Meeting of the Econometric Society in Tokyo; the Bank of Canada / Bank of Korea conference on Globalization and Optimal Monetary Policy; and the SED annual conference in Montreal. Older versions of this paper circulated under the titles "Trend Inflation and Economic Growth in the Presence of Nominal Price Contracts" and "Trend inflation, nominal rigidities, and endogenous growth". The views expressed are the authors' and do not necessarily reflect those of the Bank of Canada or its staff.

${ }^{\dagger}$ Bank of Canada, Ottawa, ON, Canada. E-mail: RAmano@BankofCanada.ca

* Princeton University, Princeton, NJ, USA. E-mail: TJCarter@Princeton.edu. Carter was with the Bank of Canada when this project first started.

${ }^{\S}$ Université Laval and CIRANO, Quebec City, QC, Canada. Email: KMoran@ecn.ULaval.ca.
} 


\section{Introduction}

The long-run relation between growth and inflation is a key topic in macroeconomics. However, it has not yet been studied in the context of nominal price and wage rigidities, despite the fact that these rigidities now figure prominently in workhorse macroeconomic models for research and policy. ${ }^{1}$ We take a first step in addressing this apparent gap in the literature by integrating staggered price- and wage-setting into a benchmark endogenous growth framework. This marriage delivers a strong growth-inflation linkage, suggesting an important channel via which inflation affects New Keynesian economies.

Our model features Taylor price and wage contracts, along with endogenous growth through expanding variety, as in Romer (1990). Monopolistically competitive firms supply a range of intermediate goods, and growth occurs as innovators design new varieties of these goods; as compensation, innovators receive equity in the intermediate good-producing sector. The sector's profits then serve as a link between growth and inflation, since real profits represent an incentive for innovation but are sensitive to inflation due to the presence of nominal rigidities.

Acting via this mechanism, inflation exerts a strong influence on long-run growth. Under our baseline calibration, shifting trend inflation from -5 to $5 \%$ per annum causes the annualized growth rate to vary within a 50 basis point range. Over thirty years, this implies as much as a $15 \%$ differential in output.

Nominal wage rigidity plays a critical role in generating these results. We find that inflation's impact on profits - and growth in turn — owes not so much to the distortive effects of price rigidity as to a somewhat unremarked consequence of wage rigidity. More specifically, with staggered wage-setting, changes in the trend rate of inflation elicit dramatic adjustments in the volume of labor available to complement intermediate goods, with strong implications for profits and growth. This "labor supply effect" so dominates the growth-inflation linkage that an experiment abstracting from wage rigidity fails to deliver a quantitatively significant relation between growth and inflation.

Aside from its effect on growth, inflation also has a dramatic impact on welfare, consistent with Lucas (1988), who argues, due to compounding, that policy choices should have strong welfare effects if they influence long-run growth. As we vary trend inflation from -5 to $5 \%$ under our baseline calibration, consumption-equivalent welfare losses reach up to $6 \%$, with most of these losses specifically attributable to inflation's effect on growth. Based on these results, we conclude that endogenous growth is an important channel via which inflation affects New Keynesian economies and that its omission may understate the welfare costs of inflation.

In terms of related literature, this paper extends several theoretical inquiries into the growth-inflation nexus. Our main contribution is our emphasis on nominal price and wage rigidities, since pre-existing models for the nexus tend to abstract from nominal inertia. Most instead subvert superneutrality by assuming a transactions role for money. Examples include Gomme (1993), Marquis and Reffett (1994), Jones and Manuelli (1995), Dotsey and Ireland (1996), Wu and Zhang (1998), Dotsey and Sarte (2000), Zhang (2000), and Gillman and Kejak

\footnotetext{
${ }^{1}$ Variants of the so-called New Keynesian model have been used to study other important monetary policy questions such as optimal monetary policy rules, zero bound on nominal interest rates, desirability of inflation targeting, optimal policy under discretion and commitment, etc. Moreover, the New Keynesian framework underpins the new generation of medium-scale macroeconomic models used in central banks as well as in the broader macroeconomic research community, and provides theoretical support to the inflation-stability strategies adopted by the majority of monetary policymakers in the industrialized world.
} 
$(2005) .^{2}$

Our work is also related to another literature concerning the importance of nominal wage inertia. In stochastic settings featuring price and wage rigidities, Erceg et al. (2000) show that wage rigidity has strong implications for optimal monetary policy, while Huang and Liu (2002) show that sticky wages are more likely to effect business cycle persistence than are sticky prices. In an effort to match empirical responses to monetary policy shocks, Christiano et al. (2005) find that wage rigidity is essential to the replication of key data moments. More recently, in a deterministic model embedding exogenous productivity growth, Amano et al. (2009) find that wage rigidity dominates price rigidity in terms of its implications for welfare and optimal inflation. We extend these findings by showing that nominal wage rigidity is essential to a New Keynesian model's capacity to deliver a strong growth-inflation linkage.

The remainder of this paper is organised as follows. Section 2 introduces our model. Section 3 characterizes and solves for the balanced growth path. We calibrate in section 4 . In section 5, we present and discuss our findings, while section 6 provides sensitivity analysis. We conclude in section 7 .

\section{Model}

This section presents a discrete-time, general-equilibrium model that links growth and inflation by integrating staggered price- and wage-setting into an endogenous growth framework. The model economy's real structure is based on an extension of Romer (1990) while its nominal rigidities take the form of Taylor (1980) price and wage contracts. ${ }^{3}$ In this section, we describe each of the economy's five agents - namely final and intermediate good-producing firms, a representative household, an innovator, and a government responsible for setting fiscal and monetary policy — before closing with a market-clearing condition.

\subsection{Final good production}

Final output $Y_{t}$ is produced using the technology

$$
Y_{t}=L_{t}^{1-\alpha} X_{t}^{\alpha}
$$

where

$$
X_{t}=\left(\int_{0}^{N_{t}} X_{j t}^{\frac{\sigma-1}{\sigma}} \mathrm{d} j\right)^{\frac{\sigma}{\sigma-1}}
$$

is a Dixit-Stiglitz aggregate over a range of intermediate goods. $N_{t}$ measures the variety of these goods available in period $t$, while $\sigma$ is the elasticity of substitution across varieties, and

\footnotetext{
${ }^{2}$ Alternate approaches rely on inflation's redistributive effects (Mino and Shibata, 1995, 2000), its role in public finance (de Gregorio, 1993; Roubini and Sala-i-Martin, 1995) and its interaction with financial frictions (Chari et al. 1996, Ho 1996, Haslag 1998, Bose 2002, Chang et al. 2007). To our knowledge, the only preexisting models that embed some form of nominal rigidity are Jones and Manuelli (1995) and Funk and Kromen (2010). Jones and Manuelli consider rigidities in the tax system, while Funk and Kromen consider sticky goods prices in isolation.

${ }^{3}$ We use Taylor contracts instead of Calvo (1983) contracts in light of evidence from Ascari (2004) that contracts of the former type are better suited to the study of inflation's macroeconomic effects when trend inflation is non-zero.
} 
$X_{j t}$ is the output of intermediate good $j$. Similarly,

$$
L_{t}=\left(\int_{0}^{1} L_{i t}^{\frac{\theta-1}{\theta}} \mathrm{d} i\right)^{\frac{\theta}{\theta-1}}
$$

is an aggregate over a (fixed) range of differentiated labor services, with $L_{i t}$ denoting the quantity of service $i$ and $\theta$ denoting the elasticity of substitution across services.

The final good-producing sector is perfectly competitive, with firms choosing their inputs to maximize profits

$$
P_{t} Y_{t}-\int_{0}^{N_{t}} P_{j t} X_{j t} \mathrm{~d} j-\int_{0}^{1} W_{i t} L_{i t} \mathrm{~d} i
$$

where $P_{t}$ is the price of final output, $P_{j t}$ is the price of intermediate good $j$, and $W_{i t}$ is a service-specific wage. The first-order condition for $X_{j t}$ is then

$$
X_{j t}=\left[\alpha L_{t}^{1-\alpha}\left(\frac{P_{j t}}{P_{t}}\right)^{-1}\right]^{\sigma} X_{t}^{1-\sigma(1-\alpha)}
$$

which implies that final good producers demand the aggregate $X_{t}$ according to

$$
X_{t}=N_{t}^{\frac{1}{(\sigma-1)(1-\alpha)}}\left(\frac{\alpha}{\Delta_{t}^{P}}\right)^{\frac{1}{1-\alpha}} L_{t}
$$

where

$$
\Delta_{t}^{P}=\left[\frac{1}{N_{t}} \int_{0}^{N_{t}}\left(\frac{P_{j t}}{P_{t}}\right)^{1-\sigma} \mathrm{d} j\right]^{\frac{1}{1-\sigma}}
$$

measures the average real price at which intermediate goods sell. Similarly, the first-order condition on $L_{i t}$ is

$$
L_{i t}=\left[(1-\alpha) X_{t}^{\alpha}\left(\frac{W_{i t}}{P_{t}}\right)^{-1}\right]^{\theta} L_{t}^{1-\theta \alpha}
$$

which implies that

$$
L_{t}=\frac{1-\alpha}{\Delta_{t}^{W} / Y_{t}}
$$

where

$$
\Delta_{t}^{W}=\left[\int_{0}^{1}\left(\frac{W_{i t}}{P_{t}}\right)^{1-\theta} \mathrm{d} i\right]^{\frac{1}{1-\theta}}
$$

gives the average real wage at which labor services are hired.

\section{$2.2 \quad$ Intermediate good production}

Intermediate goods are produced by monopolistically competitive firms that set prices using Taylor contracts. These contracts last $J$ periods, and firms are uniformly distributed across pricing cohorts. The sector operates a simple technology that generates one unit of a given intermediate good from one unit of final output. 
Let $P_{t}^{*}$ be the nominal price set by firms re-optimizing in period $t$. Suppose that firm $j$ is one such re-optimizer and that $P_{t}^{*}$ elicits demand $X_{j t}\left(P_{t}^{*}\right)$ for its output. Firm $j$ then chooses $P_{t}^{*}$ to maximize the real discounted value of the profits generated over the duration of the contract,

$$
\sum_{\tau=0}^{J-1} \beta^{\tau}\left(\frac{\lambda_{t+\tau}}{\lambda_{t}}\right)\left(\frac{P_{t}^{*}\left(1+s^{X}\right)}{P_{t+\tau}}-1\right) X_{j, t+\tau}\left(P_{t}^{*}\right)
$$

where $\beta$ and $\lambda_{t}$ are the shareholders' discount factor and marginal utility of real income, respectively, and $s^{X}$ is a subsidy. The first-order condition is

$$
P_{t}^{*}=\frac{\sigma /\left(1+s^{X}\right)}{\sigma-1}\left(\frac{\sum_{\tau=0}^{J-1} \beta^{\tau} \lambda_{t+\tau} P_{t+\tau}^{\sigma} X_{t+\tau}^{1-\sigma(1-\alpha)} L_{t+\tau}^{\sigma(1-\alpha)}}{\sum_{\tau=0}^{J-1} \beta^{\tau} \lambda_{t+\tau} P_{t+\tau}^{\sigma-1} X_{t+\tau}^{1-\sigma(1-\alpha)} L_{t+\tau}^{\sigma(1-\alpha)}}\right)
$$

\subsection{Households and labor}

We assume the presence of a multi-agent, infinitely lived representative household that aims to maximize discounted utility

$$
\sum_{t=0}^{\infty} \beta^{t}\left(\log C_{t}-\frac{1}{1+\nu} \int_{0}^{1} L_{i t}^{1+\nu} \mathrm{d} i\right)
$$

subject to the following budget constraint, which is presented in real terms:

$$
C_{t}+\left(1-s^{I}\right) I_{t}+T_{t}+\frac{B_{t}}{P_{t}}=D_{t}+\frac{1+s^{L}}{P_{t}} \int_{0}^{1} W_{i t} L_{i t} \mathrm{~d} i+\frac{B_{t-1}\left(1+r_{t-1}\right)}{P_{t}}
$$

where $C_{t}$ and $I_{t}$ are consumption and investment in "research and development" (R\&D), while $T_{t}$ is a lump-sum tax. $B_{t}$ denotes nominal holdings in one-period government bonds, which pay interest at risk-free rate $r_{t}$. $D_{t}$ denotes dividends, while $s^{I}$ and $s^{L}$ are subsidies (discussed below). Thus, the constraint's left-hand side gives household expenditures, while the righthand side gives revenues, including dividends, wage receipts, and the return on last period's lending.

In the labor market, we assume that each member $i(i \in[0,1])$ of the extended household supplies $L_{i t}$ units of differentiated labor and service-specific wages are set in a monopolistically competitive market using Taylor contracts. These contracts last $I$ periods, and services are uniformly distributed across wage-setting cohorts. The wage charged for services with contracts resetting in period $t, W_{t}^{*}$, is then chosen to satisfy the following first-order condition:

$$
\left(W_{t}^{*}\right)^{1+\theta \nu}=\frac{\theta(1-\alpha)^{\theta \nu} /\left(1+s^{L}\right)}{\theta-1}\left(\frac{\sum_{\tau=0}^{I-1} \beta^{\tau} P_{t+\tau}^{\theta(1+\nu)} X_{t+\tau}^{\alpha \theta(1+\nu)} L_{t+\tau}^{(1-\alpha \theta)(1+\nu)}}{\sum_{\tau=0}^{I-1} \beta^{\tau} \lambda_{t+\tau} P_{t+\tau}^{\theta-1} X_{t+\tau}^{\alpha \theta} L_{t+\tau}^{1-\theta \alpha}}\right)
$$

\subsection{Innovation}

The household designs new varieties of intermediate goods using an R\&D technology due to Evans et al. (1998). In period $t$, this technology enables the innovator to develop intermediate good $j \in\left(N_{t}, N_{t+1}\right]$ at real cost $\eta j^{\xi}$. R\&D thus causes variety $N_{t}$ to rise over time, which drives the growth process. 
Once a new variety has been designed, the design is patented and the patent sold to a prospective intermediate good producer. In return, the household-cum-innovator receives equity. We assume that the innovator is unaware of the pricing cohort in which the producer will operate and that new patents are uniformly distributed across cohorts. Therefore, the innovator expects that a patent designed in period $t$ will yield

$$
\mathbb{P}_{s}=\frac{1}{N_{s}} \int_{0}^{N_{s}} \mathbb{P}_{j s} \mathrm{~d} j
$$

in real dividends in each period $s \geq t+1$, where $\mathbb{P}_{j s}$ denotes the real profits that producer $j$ generates in period $s$.

Balancing these dividends against the up-front cost of $\mathrm{R} \& \mathrm{D}$, the investment

$$
I_{t}=\eta \int_{N_{t}}^{N_{t+1}} j^{\xi} \mathrm{d} j
$$

will satisfy the following zero-profit condition:

$$
\left(1-s^{I}\right) \eta N_{t+1}^{\xi}=\sum_{\tau=1}^{\infty} \beta^{\tau}\left(\frac{\lambda_{t+\tau}}{\lambda_{t}}\right) \mathbb{P}_{t+\tau}
$$

\subsection{Government}

Government's key role in this economy is to set the rate of trend inflation, $\pi=P_{t+1} / P_{t}$. Since this paper focuses on the long-run relation between growth and inflation and thus restricts attention to the economy's balanced growth path, we do not need to specify the monetary policy implementing $\pi$. That is, $\pi$ can be viewed as being set using an interest rate rule or through money growth targeting.

Government also sets fiscal policy. We follow Erceg et al. (2000) and others in using fiscal policy to offset the effects of imperfect competition, thus isolating the effects of nominal rigidity for later discussion. This requires that we characterize optimal fiscal policy in the special case of a flexible economy with price and wage contracts lasting $J=I=1$ period. With monopolistic distortions constraining the supply of labor services and intermediate goods, this policy involves the following subsidies:

$$
\begin{aligned}
s^{X} & =\frac{1}{\sigma-1} \\
s^{L} & =\frac{1}{\theta-1}
\end{aligned}
$$

A novel issue arises because our model features an additional source of distortion aside from nominal rigidity and imperfect competition. In particular, there are externalities associated with innovation: the development of the marginal design has an effect on the productivity of inframarginal designs in a sense that we make precise in section 3. We offset this effect using the investment subsidy so as to maintain our focus on nominal rigidity:

$$
s^{I}=\frac{\beta\left(\frac{\lambda_{t+1}}{\lambda_{t}}\right)^{\frac{1-\sigma(1-\alpha)}{\alpha}}\left[\left(\frac{\lambda_{t+1}}{\lambda_{t}}\right)^{\frac{(\sigma-1)(1-\alpha)}{\alpha}}-1\right]}{1-\beta\left(\frac{\lambda_{t+1}}{\lambda_{t}}\right)^{\frac{1-\sigma(1-\alpha)}{\alpha}}}
$$


With fiscal policy set according to equations 5 through 7 , it can be verified that the flexible economy recovers its first-best path. With subsidies set in this fashion, the government then chooses lump-sum transfer $T_{t}$ to balance its period budget constraint.

\subsection{Market-clearing}

With the behaviour of all the economy's agents fully specified, our model is closed by a single market-clearing condition: output must be fully allocated across its three uses, namely consumption, R\&D, and the production of intermediate goods. That is,

$$
Y_{t}=C_{t}+I_{t}+\int_{0}^{N_{t}} X_{j t} \mathrm{~d} j
$$

\section{Balanced growth path}

In order to characterize the long-run relation between growth and inflation, we need to find our model's balanced growth path (BGP). Along this path, the economy equilibrates such that (i) all prices and quantities grow at constant, though potentially unequal, rates; (ii) the consumption-to-output ratio $C_{t} / Y_{t}$ is constant; and (iii) aggregate labor $L_{t}$ is constant. In this section, we highlight some of the BGP's key properties, then present a system that solves for the BGP.

Price-setting along the BGP. The path's key property viz-à-viz price-setting in the intermediate good-producing sector is that $P_{t}^{*} / P_{t}$, the mark-up to which firms re-optimize, is constant when growth is balanced. More specifically, the first-order condition for $P_{t}^{*}$ (expression 2) gives

$$
\frac{P_{t}^{*}}{P_{t}}=\frac{\sigma /\left(1+s^{X}\right)}{(\sigma-1)}\left[\frac{\sum_{\tau=0}^{J-1}\left\{\beta\left(\frac{1}{g}\right)^{\frac{(\sigma-1)(1-\alpha)}{\alpha}} \pi^{\sigma}\right\}^{\tau}}{\sum_{\tau=0}^{J-1}\left\{\beta\left(\frac{1}{g}\right)^{\frac{(\sigma-1)(1-\alpha)}{\alpha}} \pi^{\sigma-1}\right\}^{\tau}}\right]
$$

where $g=Y_{t+1} / Y_{t}$ is the long-run growth rate. ${ }^{4}$ Furthermore, with all firms pricing in this fashion, the sector's average mark-up is constant and given by

$$
\Delta_{t}^{P}=\frac{P_{t}^{*}}{P_{t}}\left[\frac{1}{J} \sum_{\tau=0}^{J-1}\left(\frac{1}{\pi}\right)^{\tau(1-\sigma)}\right]^{\frac{1}{1-\sigma}}
$$

Wage-setting along the BGP. Within the labor market, our main observation is that $W_{t}^{*} / P_{t}$, the real wage to which households re-optimize, grows proportionally with real output. More specifically, the first-order condition on $W_{t}^{*}$ (expression 3) gives

$$
\frac{W_{t}^{*}}{P_{t}}=Y_{t}\left[\left(\frac{\theta /\left(1+s^{L}\right)}{(\theta-1)}\right)\left(\frac{C_{t}}{Y_{t}}\right)\left(\frac{\sum_{\tau=0}^{I-1}\left\{\beta(\pi g)^{\theta(1+\nu)}\right\}^{\tau}}{\sum_{\tau=0}^{I-1}\left\{\beta(\pi g)^{\theta-1}\right\}^{\tau}}\right)\left(\frac{1-\alpha}{\frac{1}{I} \sum_{\tau=0}^{I-1}\{\pi g\}^{\tau(\theta-1)}}\right)^{\nu}\right]^{\frac{1}{1+\nu}}
$$

\footnotetext{
${ }^{4}$ Along the BGP, consumption and investment grow at the same rate as output, while varieties $N_{t}$ expand at the rate $g^{(1-\alpha)(\sigma-1) / \alpha}$ and nominal wages at rate $g \pi$.
} 
With wages for all services set in this manner, the average real wage also grows proportionally with $Y_{t}$ and is given by

$$
\Delta_{t}^{W}=\frac{W_{t}^{*}}{P_{t}}\left[\frac{1}{I} \sum_{\tau=0}^{I-1}\left(\frac{1}{\pi g}\right)^{\tau(1-\theta)}\right]^{\frac{1}{1-\theta}}
$$

These trends in $W_{t}^{*} / P_{t}$ and $\Delta_{t}^{W}$ owe to growth driving down the marginal utility of real income and the corresponding requirement that real wages rise in order for the BGP to elicit a constant labor supply from households.

Intermediate good producers' profits along the BGP. Turning to the intermediate good-producing sector's profits, we find that in period $t$ firm $j$ has real profits

$$
\mathbb{P}_{j t}=\left(\frac{N_{t}}{\left(\Delta_{t}^{P}\right)^{\sigma-1}}\right)^{\frac{1-\sigma(1-\alpha)}{(\sigma-1)(1-\alpha)}} \alpha^{\frac{1}{1-\alpha}} L_{t}\left(\frac{P_{j t}}{P_{t}}\right)^{-\sigma}\left(\frac{P_{j t}\left(1+s^{X}\right)}{P_{t}}-1\right)
$$

Therefore, since variety $N_{t}$ expands along the BGP, profits associated with each variety fall over time if intermediate goods are sufficiently substitutable $\left(\sigma>\frac{1}{1-\alpha}\right)$ and rise if goods are sufficiently complementary.

To understand why variety $N_{t}$ exerts such an influence on the intermediate good-producing sector's profits, revisit the demand function for intermediate good $j$ :

$$
X_{j t}=\left[\alpha L_{t}^{1-\alpha}\left(\frac{P_{j t}}{P_{t}}\right)^{-1}\right]^{\sigma} X_{t}^{1-\sigma(1-\alpha)}
$$

From this expression we see that demand for $j$ depends on the output of all other intermediate goods via the aggregate $X_{t}$. For example, when goods are sufficiently substitutable $\left(\sigma>\frac{1}{1-\alpha}\right)$, an increase in the quantity of good $i \neq j$ reduces demand for $j$ through its impact on $X_{t}$. This effect constitutes a demand externality in the sense of Blanchard and Kiyotaki (1987).

With this externality operating, any factor that impacts the aggregate $X_{t}$ in turns affects each intermediate good producer's profits. Variety $N_{t}$ qualifies as one such factor since, as shown in subsection 2.1,

$$
X_{t}=N_{t}^{\frac{1}{(\sigma-1)(1-\alpha)}}\left(\frac{\alpha}{\Delta_{t}^{P}}\right)^{\frac{1}{1-\alpha}} L_{t}
$$

that is, $X_{t}$ rises with the variety of its components. Whether this effect causes profits to rise or fall over time then depends on the externality's direction, as determined by the inequality $\sigma \lessgtr \frac{1}{1-\alpha}$.

Aside from linking profits and variety $N_{t}$ in this way, the demand externality also links profits to $\Delta_{t}^{P}$, our measure of the intermediate good-producing sector's average mark-up. From equation 13 we see that the aggregate $X_{t}$ falls with $\Delta_{t}^{P}$ — that is, $X_{t}$ falls with the average mark-up at which its components are sold. Whether profits in turn rise or fall then depends on the critical inequality $\sigma \lessgtr \frac{1}{1-\alpha}$.

$R \& D$ along the BGP. Given that the intermediate good-producing sector's profits represent an incentive for innovation, the model admits implications for R\&D. To see this result, we 
substitute for profits in the innovator's marginal condition (equation 4):

$$
\eta N_{t}^{\xi}=\left(\frac{\beta\left(\frac{\lambda_{t}}{\lambda_{t-1}}\right)}{1-\beta\left(\frac{\lambda_{t}}{\lambda_{t-1}}\right)}\right)\left(\frac{N_{t}}{\left(\Delta_{t}^{P}\right)^{\sigma-1}}\right)^{\frac{1-\sigma(1-\alpha)}{(\sigma-1)(1-\alpha)}} \alpha^{\frac{1}{1-\alpha}} L_{t}\left[\frac{1}{J} \sum_{\tau=0}^{J-I}\left(\frac{P_{t-\tau}^{*}}{P_{t}}\right)^{-\sigma}\left(\frac{P_{t-\tau}^{*}\left(1+s^{X}\right)}{P_{t}}-1\right)\right]
$$

Since innovation costs are on the left-hand side and its benefits on the right-hand side, we see that both costs and benefits depend on $N_{t}$, though via different channels: for costs, this dependence is inherent in the R\&D technology, while for benefits it follows from the demand externality.

This disparity has the potential to make equation 14 non-stationary, leading to unbalanced growth. If, for example, $\xi=0$ while $\sigma<\frac{1}{1-\alpha}$, then benefits would rise with $N_{t}$ despite costs' holding constant, making growth explosive. Thus balanced growth requires that $\xi$ be set to ensure stationarity in equation 14. That is, $\xi$ must be chosen such that costs rise (or fall) to offset the effects of the demand externality. This balance is achieved under the following parameter restriction, which we borrow from Evans et al. (1998):

$$
\xi=\frac{1-\sigma(1-\alpha)}{(\sigma-1)(1-\alpha)}
$$

Market-clearing along the BGP. Turning finally to the allocation of final output across its various uses, we note that the BGP allocates a constant share of output to R\&D. The share of output allocated to the production of intermediate goods is also constant. It can be shown that these shares are respectively given by

$$
\frac{I_{t}}{Y_{t}}=\frac{\eta(g-1)}{1+\xi}\left(\frac{\Delta_{t}^{P}}{\alpha}\right)^{\frac{\alpha}{1-\alpha}} \frac{1}{L_{t}}
$$

and

$$
\frac{\int_{0}^{N_{t}} X_{j t} \mathrm{~d} j}{Y_{t}}=\alpha\left(\Delta_{t}^{P}\right)^{\sigma-1}\left(\frac{P_{t}^{*}}{P_{t}}\right)^{-\sigma}\left(\frac{1}{J} \sum_{\tau=0}^{J-1} \pi^{\tau \sigma}\right)
$$

so market-clearing implies that

$$
\frac{C_{t}}{Y_{t}}=1-\alpha\left(\Delta_{t}^{P}\right)^{\sigma-1}\left(\frac{P_{t}^{*}}{P_{t}}\right)^{-\sigma}\left(\frac{1}{J} \sum_{\tau=0}^{J-1} \pi^{\tau \sigma}\right)-\frac{\eta(g-1)}{1+\xi}\left(\frac{\Delta_{t}^{P}}{\alpha}\right)^{\frac{\alpha}{1-\alpha}} \frac{1}{L_{t}}
$$

Solution. Given parameters and a chosen value for trend inflation $\pi$, expressions 1, 8, 9, 10, 11, 14 and 16 together constitute a stationary system of seven equations in seven unknowns. 
These unknowns are $L_{t}, P_{t}^{*} / P_{t}, \Delta_{t}^{P}, W_{t}^{*} / P_{t} Y_{t}, \Delta_{t}^{W} / Y_{t}, g$, and $C_{t} / Y_{t}$, and the system is

$$
\begin{aligned}
L_{t} & =\frac{1-\alpha}{\Delta_{t}^{W} / Y_{t}} \\
\frac{P_{t}^{*}}{P_{t}} & =\frac{\sigma /\left(1+s^{X}\right)}{(\sigma-1)}\left[\frac{\sum_{\tau=0}^{J-1}\left\{\beta\left(\frac{1}{g}\right)^{\frac{(\sigma-1)(1-\alpha)}{\alpha}} \pi^{\sigma}\right\}^{\tau}}{\sum_{\tau=0}^{J-1}\left\{\beta\left(\frac{1}{g}\right)^{\frac{(\sigma-1)(1-\alpha)}{\alpha}} \pi^{\sigma-1}\right\}^{\tau}}\right] \\
\Delta_{t}^{P} & =\frac{P_{t}^{*}}{P_{t}}\left[\frac{1}{J} \sum_{\tau=0}^{J-1}\left(\frac{1}{\pi}\right)^{\tau(1-\sigma)}\right]^{\frac{1}{1-\sigma}} \\
\frac{W_{t}^{*}}{P_{t} Y_{t}} & =\left[\left(\frac{\theta /\left(1+s^{L}\right)}{(\theta-1)}\right)\left(\frac{C_{t}}{Y_{t}}\right)\left(\frac{\sum_{\tau=0}^{I-1}\left\{\beta(\pi g)^{\theta(1+\nu)}\right\}^{\tau}}{\sum_{\tau=0}^{I-1}\left\{\beta(\pi g)^{\theta-1}\right\}^{\tau}}\right)\left(\frac{1-\alpha}{\frac{1}{I} \sum_{\tau=0}^{I-1}\{\pi g\}^{\tau(\theta-1)}}\right)^{\nu}\right]^{\frac{1}{1+\nu}} \\
\frac{\Delta_{t}^{W}}{Y_{t}} & \left.=\frac{W_{t}^{*}}{P_{t} Y_{t}}\left[\frac{1}{I} \sum_{\tau=0}^{I-1}\left(\frac{1}{\pi g}\right)^{\tau(1-\theta)}\right]^{\frac{1}{1-\theta}}\right]^{\frac{1-\sigma(1-\alpha)}{1-\alpha}} \alpha^{\frac{1}{1-\alpha}} L_{t}\left[\frac{1}{J} \sum_{\tau=0}^{J-I}\left(\frac{P_{t}^{*} / P_{t}}{\pi^{\tau}}\right)^{-\sigma}\left(\frac{\left(P_{t}^{*} / P_{t}\right)\left(1+s^{X}\right)}{\pi^{\tau}}-1\right)\right] \\
\eta & =\left(\frac{\beta}{g-\beta}\right)\left(\frac{1}{\Delta_{t}^{P}}\right)^{\frac{\alpha}{C_{t}}} \frac{1}{Y_{t}} \quad=1-\alpha\left(\Delta_{t}^{P}\right)^{\sigma-1}\left(\frac{P_{t}^{*}}{P_{t}}\right)^{-\sigma}\left(\frac{1}{J} \sum_{\tau=0}^{J-1} \pi^{\tau \sigma}\right)-\frac{\eta(g-1)}{1+\xi}\left(\frac{\Delta_{t}^{P}}{\alpha}\right)^{\frac{\alpha}{1-\alpha}} \frac{1}{L_{t}}
\end{aligned}
$$

where equation 17 follows from the innovator's marginal condition when we impose the parameter restriction from Evans et al. (1998).

\section{Calibration}

This section presents our baseline calibration. We begin with the parameters governing nominal rigidity, namely $J$, the length of price contracts, and $I$, the length of wage contracts. Taking each period as one quarter, we choose $J=2$ in line with micro-evidence from Bils and Klenow (2004). As for wage contracts, we set $I=4$, consistent with the calibration in Erceg et al. (2000), and Huang and Liu (2002), and estimation in Christiano et al. (2005) and Smets and Wouters (2007). Further support for this value comes from Taylor (1999), which places the average frequency of US wage adjustment at one year based on a review of the empirical literature.

We realize that wage contract lengths are likely endogenous to the level of trend inflation. However, research suggests that the relevant range of wage contract lengths is relatively narrow. Cecchetti (1987), for instance, finds that the average period between union wage changes in the United States was about seven quarters in the 1950s and 1960s, when inflation averaged around 2.2 percent, and then fell to four quarters in the $1970 \mathrm{~s}$, when inflation averaged around 7.1 percent (and sometimes reached double-digit levels). Moreover, Fregert and Jonung (2006) found that in Sweden from 1908 to 2005, average contract lengths rarely fell below four quarters, even in periods when inflation was relatively high. In this sense, our baseline case of four-quarter wage contracts may represent a lower bound, and in any case section 6 will show that our model still delivers a substantial growth-inflation linkage even if duration is halved to two quarters.

The R\&D parameter, $\eta$, is chosen so that real output grows at rate $3 \%$ per annum when inflation is at $2.5 \%$, broadly consistent with pre-crisis experience in the United States. As 
for $\xi$, we ensure balanced growth by setting $\xi$ at the level implied by equation 15 when $\alpha$ and $\sigma$ are calibrated as follows. We choose $\alpha$ to give labor share $1-\alpha=2 / 3$ in final goods production and set $\sigma$ so that intermediate good producers facing $2.5 \%$ inflation re-optimize to a 25\% mark-up over marginal cost. The latter is consistent with micro-evidence supporting mark-ups in the 10 to $40 \%$ range (Basu, 1996; Basu and Fernald, 1997). With $\alpha$ and $\sigma$ assigned these values, we find that $\sigma>\frac{1}{1-\alpha}$, so the demand externality of section 3 is negative implying that intermediate goods are substitutable to the point that demand for good $j$ falls with the output of each good $i \neq j$.

In regard to the labor market parameters, the elasticity of substitution among labor services, $\theta$, is set to 12 , consistent with the value reported in Kim (2000) and Basu (1996). The degree of convexity in the disutility of labor, $\nu$, is set to one, following Hornstein and Wolman (2005).

Finally, we set the discount factor, $\beta=0.99$, and choose subsidies $s^{X}, s^{L}$ and $s^{I}$ to satisfy equations 5 through 7 in subsection 2.5 .

\section{Results}

With the model calibrated, we conduct a policy experiment by varying the rate of trend inflation from -5 to $5 \%$ per annum and measuring how changes in this range impact the economy's BGP. Our main results concern inflation's impact on the long-run growth rate and are presented in subsection 5.1, while subsection 5.2 explores inflation's implications for welfare along the BGP. All rates reported in this section are quoted on an annualized basis.

\subsection{Inflation's impact on long-run growth}

The long-run relation between growth and inflation is presented in Figure 1. Our most important finding is that inflation exerts a strong influence on growth: as inflation shifts from -5 to $5 \%$, the range over which the growth rate varies spans nearly 50 basis points, implying up to a $15 \%$ output differential after thirty years. Our estimate of inflation's impact on the economy's growth rate appears to be on the higher end of those reported in earlier work. Gomme (1993), for instance, finds output growth to vary only by about 8 basis points over his model's optimal to 10\% inflation interval. Dotsey and Ireland (1996) calculate a 20 basis point decline in growth when their economy moves from the Friedman rule to $4 \%$ inflation. We also find that maximum growth requires substantial deflation, namely at rate $3.15 \%$.

What mechanism drives these results? Our model links growth and inflation via the intermediate good-producing sector's profits, since real profits represent an incentive for R\&D but are sensitive to changes in the price level. More formally, if we re-arrange the innovator's marginal condition as given in equation 17, we find that

$$
g=\beta+\left(\frac{\beta}{\eta}\right)\left(\frac{\mathbb{P}_{t}}{N_{t}^{\xi}}\right)
$$

Growth is thus an increasing function of (variety-normalised) profits and so varies with inflation to the extent that profits themselves vary with inflation. In particular, we isolate three channels 
through which inflation impacts profits:

$$
\frac{\mathbb{P}_{t}}{N_{t}^{\xi}}=\underbrace{\left(\frac{1}{\Delta_{t}^{P}}\right)^{\frac{1-\sigma(1-\alpha)}{\sigma-1}}}_{\begin{array}{c}
\text { average } \\
\text { mark-up } \\
\text { effect }
\end{array}} \alpha^{\frac{1}{1-\alpha}} \underbrace{\left[L_{t}\right.}_{\begin{array}{c}
\text { labor } \\
\text { supply } \\
\text { effect }
\end{array}} \underbrace{\left[\frac{1}{J} \sum_{\tau=0}^{J-I}\left(\frac{P_{t-\tau}^{*}}{P_{t}}\right)^{-\sigma}\left(\frac{P_{t-\tau}^{*}\left(1+s^{X}\right)}{P_{t}}-1\right)\right]}_{\text {direct effect }}
$$

The direct effect captures inflation's impact via quantities that firms choose directly, namely the cohort-specific mark-ups $P_{t-\tau}^{*} / P_{t}$, while the other two effects capture general-equilibrium channels. More specifically, the average mark-up effect captures the demand externality's role in linking profits with the average mark-up $\Delta_{t}^{P}$, as explained in section 3 , while the labor supply effect captures the tendency for profits to rise with the amount of labor $L_{t}$ available to complement intermediate goods. ${ }^{5}$

The direct effect on growth is minimized at zero inflation, since inflation at this rate eliminates the distortion associated with price rigidity, as in King and Wolman (1996). ${ }^{6}$ In contrast, whether $\Delta_{t}^{P}$ rises or falls with inflation depends on the balance of two countervailing forces: as in Wolman (2001), higher inflation leads re-optimizing price-setters to "front-end load" more aggressively, but it also accelerates real price erosion among non-re-optimizers. Similar forces act on the average real wage $\Delta_{t}^{W}$, which determines $L_{t}$ through equation 1 . In particular, higher trend inflation could reduce $L_{t}$ by leading wage-setters to "front-end load" and thereby increase the average wage-markup. In turn, the rise in the wage-markup reduces availability of aggregate labor input $L_{t}$ and thus profits. To resolve these ambiguities, we use Figure 2 to plot our three effects against inflation.

From Figure 2, we see that these effects vary with inflation in disparate ways: the direct and labor supply effects peak at zero and $-3.09 \%$ inflation respectively, while the average mark-up effect is consistently decreasing with inflation on the -5 to $5 \%$ range. This suggests some tension in the relation between profits and inflation. For example, though zero inflation uniquely facilitates optimal pricing for firms that take $L_{t}$ as given, these firms also prefer some deviation to a deflationary trend since it delivers higher $L_{t}$ and thus higher profits via the labor supply effect. Given that the profit-maximizing deviation involves inflation at a rate slightly below that at which $L_{t}$ is maximized, we conclude that the labor supply effect dominates the growth-inflation linkage, with the average mark-up effect exerting a secondary influence. This indicates that wage rigidity plays a key role in generating our growth results, a point to which we return in section 6 .

\footnotetext{
${ }^{5}$ An analog to this labor supply effect drives the results generated in Gomme (1993), Jones and Manuelli (1995), Dotsey and Ireland (1996), and Gillman and Kejak (2005), among others, despite the fact that these models abstract from nominal rigidity. In these models, growth is driven by investment in capital, physical or otherwise, and labour complements capital in production; an inflation tax on wages then reduces labour supply and thus retards growth via the return to capital. In some settings, the reduction in labour supply is enhanced as households, aiming to economise on money holdings, reallocate their time to shopping and the production of credit services.

${ }^{6}$ More specifically, along the BGP, a producer facing zero inflation is able to maintain the mark-up at the level for which the producer would opt in a flexible economy. This can be verified from the intermediate good producers' first-order condition, given in equation 8.
} 


\subsection{Implications for welfare}

We now consider the implications of trend inflation for welfare along the BGP. Consumptionequivalent welfare costs are graphed in Figure 3. We compute these costs relative to the economy's first-best BGP. More specifically, these costs give the percentage increase in each period's consumption needed to achieve first-best welfare.

We find welfare costs to be sizeable, reaching about $6 \%$ as we raise inflation from -5 to $5 \%$. Along this margin, the model generates relatively larger effects than earlier work in this literature which focussed primarily on a transaction role for money to introduce an effect of inflation on endogenous growth. Indeed, our baseline model generates a welfare cost of $4.7 \%$ for an inflation rate of $4 \%$ relative to its optimal level, whereas Dotsey and Ireland's M1 specification leads to welfare cost of about 3.1\%. Gomme (1993) calculates a welfare cost of approximately $0.02 \%$ when inflation moves from the Friedman rule to $10 \%$. Moreover, we find that maximum welfare requires substantial deflation, $3.14 \%$, slightly different from the growth-maximizing deflation rate $(3.15 \%)$ mentioned in the previous section.

At this point it is useful to examine two questions. First, why does our model identify a deflationary trend as optimal? Second, are inflation's welfare costs specifically attributable to the endogenous growth mechanism? (After all, with nominal rigidities operating, inflation would prove costly even in a model with exogenous growth.) We answer these questions in turn.

To understand the model's prescription for deflation, note that with fiscal policy set as specified in section 2, there exist only two obstacles to first-best outcomes, namely the distortions stemming from nominal price and wage rigidity. The distortion associated with price rigidity is eliminated at zero inflation. On the other hand, as in Amano et al. (2009), deflation at the rate of output growth is required to eliminate the distortion associated with wage rigidity. $^{7}$ We find that a deflation rate of $3.15 \%$ exactly offsets the economy's growth rate. That welfare peaks at $3.14 \%$ deflation then indicates that wage rigidity is a more important source of distortion than is price rigidity. The model thus delivers a prescription for deflation without accommodating a transactions role for money — that is, without appeal to Friedman's rule.

To learn whether inflation's welfare costs are specifically attributable to endogenous growth, we decompose these costs as in Gomme (1993). With initial variety $N_{0}$ normalised to 1 , welfare is given by

$$
\left(\frac{1}{1-\beta}\right) \log \left(\frac{C_{t}}{N_{t}^{1+\xi}}\right)+\frac{\beta}{(1-\beta)^{2}} \log (g)-\left(\frac{1}{1-\beta}\right)\left(\frac{1}{1+\nu}\right) \int_{0}^{1} L_{i t}^{1+\nu} \mathrm{d} i
$$

and thus depends on three factors, namely consumption, growth, and labor, respectively captured by the stationary variables $C_{t} / N_{t}^{1+\xi}, g$, and $\int_{0}^{1} L_{i t}^{1+\nu} \mathrm{d} i$. To gauge each variable's contribution to welfare, we follow Gomme in asking what losses (or gains) would obtain if the competitive BGP differed from the first-best BGP only in terms of that one variable. These losses are plotted against inflation in Figure 4 and then summarized in Table 1 . We see that the contribution from growth dominates those from consumption and labor. At 0, 2, 5 and $10 \%$ inflation, the contribution from growth more than doubles the other two combined in

\footnotetext{
${ }^{7}$ More specifically, along the BGP, a wage-setter facing inflation at rate $\pi=g^{-1}$ is able to achieve a path for real wage consistent with the one arising in a flexible economy. This can be seen from the wage-setting condition, equation 10 .
} 
absolute value. We thus conclude that most of inflation's welfare costs indeed stem from its effect on growth. ${ }^{8}$

\section{Sensitivity analysis}

Results for alternate calibrations are presented in Figures 5 and 6. In particular, Figure 5 reports growth and welfare results for alternate degrees of price and wage rigidity, while Figure 6 documents the influence of other parameters.

Our main result in this section has to do with the importance of nominal wage rigidity. In the left panel of Figure 5, the black dashed line gives the relation between growth and inflation that would obtain if wage contracts only lasted $I=2$ quarters, while the dotted red line represents the case where wages are flexible $(I=1)$. The right panel of Figure 5 reports welfare results in an analogous fashion. In both panels, our baseline results are given in solid blue so as to facilitate comparison. We see that inflation still exerts substantial effects on growth and welfare even when wage contract duration is halved to two quarters. However, if we assume fully flexible wages, then inflation exerts virtually no effect on growth and welfare. This is because the shift to flexible wages shuts down the labor supply effect, which section 5 identified as the main channel linking growth and inflation.

In contrast, we find that nominal price rigidity plays a smaller role in generating our results. In Figure 5, the dash-dotted green lines give growth and welfare results for the case where price contracts only last $J=1$ quarter. We see that our results are essentially unchanged under this alternate calibration.

We now turn our attention to the parameter $\theta$, the elasticity of substitution among labour services. In Figure 6, the black dashed lines report results for an alternate calibration under which labour services are less substitutable, namely with $\theta=4$. In this case, as a given service experiences real wage erosion, firms substitute towards that service less aggressively than would otherwise be the case. The labor supply effect thus weakens, as does the growthinflation linkage.

On the other hand, our findings are relatively insensitive to changes in the parameter $\sigma$, the elasticity of substitution among intermediate goods. In Figure 6, the dotted red lines give results for the case where intermediate goods are less substitutable. In particular, we have chosen $\sigma$ such that firms facing $2.5 \%$ inflation now re-optimize to a $40 \%$ mark-up. This adjustment leaves our results essentially unchanged.

For completeness, we finally consider an alternate calibration under which the disutility of labour is less convex. In Figure 6, the dash-dotted green lines represent the case where $\nu=0.5$. We find that this adjustment leaves our findings virtually unchanged.

To summarize: the magnitude of the growth-inflation is sensitive to degree of nominal wage rigidity, along with a closely related parameter governing the substitutability of labour services. This conclusion is similar to the finding that business cycle persistence in Huang and Liu (2002) hinges critically on the calibration of labor market parameters. That wage

\footnotetext{
${ }^{8}$ Our results also suggest that models abstracting from endogenous growth are liable to understate inflation's welfare costs. Indeed, we find that previous models examining the effects of price and wage rigidity in the presence of exogenous growth deliver costs much lower than those reported here. Amano et al., for example, estimate that inflation in the 0 to $4 \%$ range elicits losses less than half those reported here. Canzoneri et al. (2007) and Wing and Po (forthcoming) also report substantially lower losses.
} 
rigidity proves key to the emergence of a strong growth-inflation linkage extends a growing literature on the importance of nominal wage inertia, including Erceg et al. (2000), Huang and Liu (2002), Christiano et al. (2005), and Amano et al. (2009).

\section{Conclusion}

In this paper, we used a version of the workhorse New Keynesian model to study the long-run relation between growth and inflation. More specifically, we integrated Taylor price and wage contracts into a benchmark model for endogenous growth through expanding variety. In this setting, an intuitive mechanism links growth and inflation via the incentive to innovate. When parameters are calibrated to standard values, the linkage is strong: the annualised growth rate varies over a 50 basis point range as we adjust inflation from -5 to $5 \%$, implying up to a $15 \%$ differential in output after thirty years. Furthermore, inflation generates large welfare costs as its growth effects compound. That sticky wages play a critical role in generating these results extends a growing literature on the importance of nominal wage inertia. More generally, our findings identify endogenous growth as a key channel via which inflation impacts New Keynesian economies.

There are several directions in which our work can be extended. In particular, given our emphasis on the effects of sticky wages, natural next steps would be to endogenize wage rigidity and/or to introduce non-allocative wages. Furthermore, this paper isolated the effects of nominal rigidity by assuming that subsidies were used to offset distortions associated with imperfect competition and externalities in the R\&D sector; future work could aim to consider settings in which these subsidies are unavailable to policymakers.

\section{References}

Amano, R., Moran, K., Murchison, S., and Rennison, A. (2009). Trend inflation, wage and price rigidities, and productivity growth. Journal of Monetary Economics, 56(3):353-64.

Ascari, G. (2004). Staggered prices and trend inflation: Some nuisances. Review of Economic Dynamics, 7(3):642-67.

Basu, S. (1996). Procyclical productivity: Increasing returns or cyclical utilization? Quarterly Journal of Economics, 111(3):719-51.

Basu, S. and Fernald, J. G. (1997). Returns to scale in U.S. production: Estimates and implications. Journal of Political Economy, 105(2):249-83.

Bils, M. and Klenow, P. J. (2004). Some evidence on the importance of sticky prices. Journal of Political Economy, 112(5):947-85.

Blanchard, O. J. and Kiyotaki, N. (1987). Monopolistic competition and the effects of aggregate demand. American Economic Review, 77(4):746-66.

Bose, N. (2002). Inflation, the credit market, and economic growth. Oxford Economic Papers, $54(3): 412-34$. 
Calvo, G. (1983). Staggered prices in a utility-maxmizing framework. Journal of Monetary Economics, 12(3):383-98.

Canzoneri, M., Cumby, R., and Diba, B. (2007). The cost of nominal rigidity in NNS models. Journal of Money, Credit, and Banking, 39:1563-86.

Cecchetti, S. (1987). Indexation and incomes policy: A study of wage adjustment in unionized manufacturing. Journal of Labor Economics, 5(3):391-412.

Chang, J.-J., Chang, W.-Y., Lai, C.-C., and Wang, P. (2007). Equilibrium dynamics in an endogenous growth model of money and banking. Journal of Money, Credit and Banking, $39(7): 1683-710$.

Chari, V., Jones, L. E., and Manuelli, R. E. (1996). Inflation, growth, and financial intermediation. Review, 78(3):41-58. Federal Reserve Bank of St. Louis.

Christiano, L. J., Eichenbaum, M., and Evans, C. L. (2005). Nominal rigidities and the dynamic effects of a shock to monetary policy. Journal of Political Economy, 113(1):1-45.

de Gregorio, J. (1993). Inflation, taxation, and long-run growth. Journal of Monetary Economics, 31(3):271-98.

Dotsey, M. and Ireland, P. (1996). The welfare cost of inflation in general equilibrium. Journal of Monetary Economics, 37(1):29-47.

Dotsey, M. and Sarte, P. D. (2000). Inflation uncertainty and growth in a cash-in-advance economy. Journal of Monetary Economics, 45(3):631-55.

Erceg, C. K., Henderson, D. W., and Levin, A. T. (2000). Optimal monetary policy with staggered wage and price contracts. Journal of Monetary Economics, 46(2):281-313.

Evans, G., Honkapohja, S., and Romer, P. M. (1998). Growth cycles. American Economic Review, 88(3):495-515.

Fregert, K. and Jonung, L. (2006). Policy rule evaluation by contract-makers: 100 years of contract length in sweden. Economic Paper no. 270, European Commission DirectorateGeneral for Economic and Financial Affairs.

Funk, P. and Kromen, B. (2010). Inflation and innovation-driven growth. B.E. Journal of Macroeconomics, 10(1). "Topics", article no. 23.

Gillman, M. and Kejak, M. (2005). Inflation and balanced-path growth with alternative payment mechanisms. Economic Journal, 115(500):247-70.

Gomme, P. (1993). Money and growth revisited : Measuring the costs of inflation in an endogenous growth model. Journal of Monetary Economics, 32(1):51-77.

Haslag, J. H. (1998). Monetary policy, banking, and growth. Economic Inquiry, 36(3):489-500.

Ho, W.-M. (1996). Imperfect information, money, and economic growth. Journal of Money, Credit and Banking, 28(4):578-603. 
Hornstein, A. and Wolman, A. L. (2005). Trend inflation, firm-specific capital, and sticky prices. Economic Quarterly, 91(4):57-83. Federal Reserve Bank of Richmond.

Huang, K. X. and Liu, Z. (2002). Staggered price-setting, staggered wage-setting, and business cycle persistence. Journal of Monetary Economics, 49(2):405-33.

Jones, L. E. and Manuelli, R. E. (1995). Growth and the effects of inflation. Journal of Economic Dynamics and Control, 19(8):1405-28.

Kim, J. (2000). Constructing and estimating a realistic optimizing model of monetary policy. Journal of Monetary Economics, 45(2):329-59.

King, R. G. and Wolman, A. L. (1996). Inflation targeting in a St. Louis model of the 21st century. Review, 78(3):83-107. Federal Reserve Bank of St. Louis.

Lucas, R. J. (1988). On the mechanics of economic development. Journal of Monetary Economics, 22(1):3-42.

Marquis, M. H. and Reffett, K. L. (1994). New technology spillovers into the payment system. Economic Journal, 104(426):1123-38.

Mino, K. and Shibata, A. (1995). Monetary policy, overlapping generations, and patterns of growth. Economica, 62(246):179-94.

Mino, K. and Shibata, A. (2000). Growth and welfare effects of monetary expansion in an overlapping-generations economy. Japanese Economic Review, 51(1):407-30.

Romer, P. M. (1990). Endogenous technological change. Journal of Political Economy, 98(5):S71-102.

Roubini, N. and Sala-i-Martin, X. (1995). A growth model of inflation, tax evasion, and financial repression. Journal of Monetary Economics, 35(2):275-301.

Smets, F. and Wouters, R. (2007). Shocks and frictions in us business cycles: A bayesian dsge approach. American Economic Review, 97:586-606.

Taylor, J. B. (1980). Aggregate dynamics and staggered contracts. Journal of Political Economy, 88(1):1-23.

Taylor, J. B. (1999). Staggered price and wage setting in macroeconomics. In Taylor, J. B. and Woodford, M., editors, Handbook of Macroeconomics, Volume 1. Elsevier Science B.V., New York.

Wolman, A. L. (2001). A primer on optimal monetary policy with staggered price-setting. Economic Quarterly, 87(4):27-52. Federal Reserve Bank of Richmond.

Wu, Y. and Zhang, J. (1998). Endogenous growth and the welfare costs of inflation: a reconsideration. Journal of Economic Dynamics and Control, 22(3):465-82.

Zhang, J. (2000). Inflation and growth: pecuniary transactions costs and qualitative equivalence. Journal of Money, Credit and Banking, 32(1):1-12. 
Figure 1: Long-run relation between growth and inflation

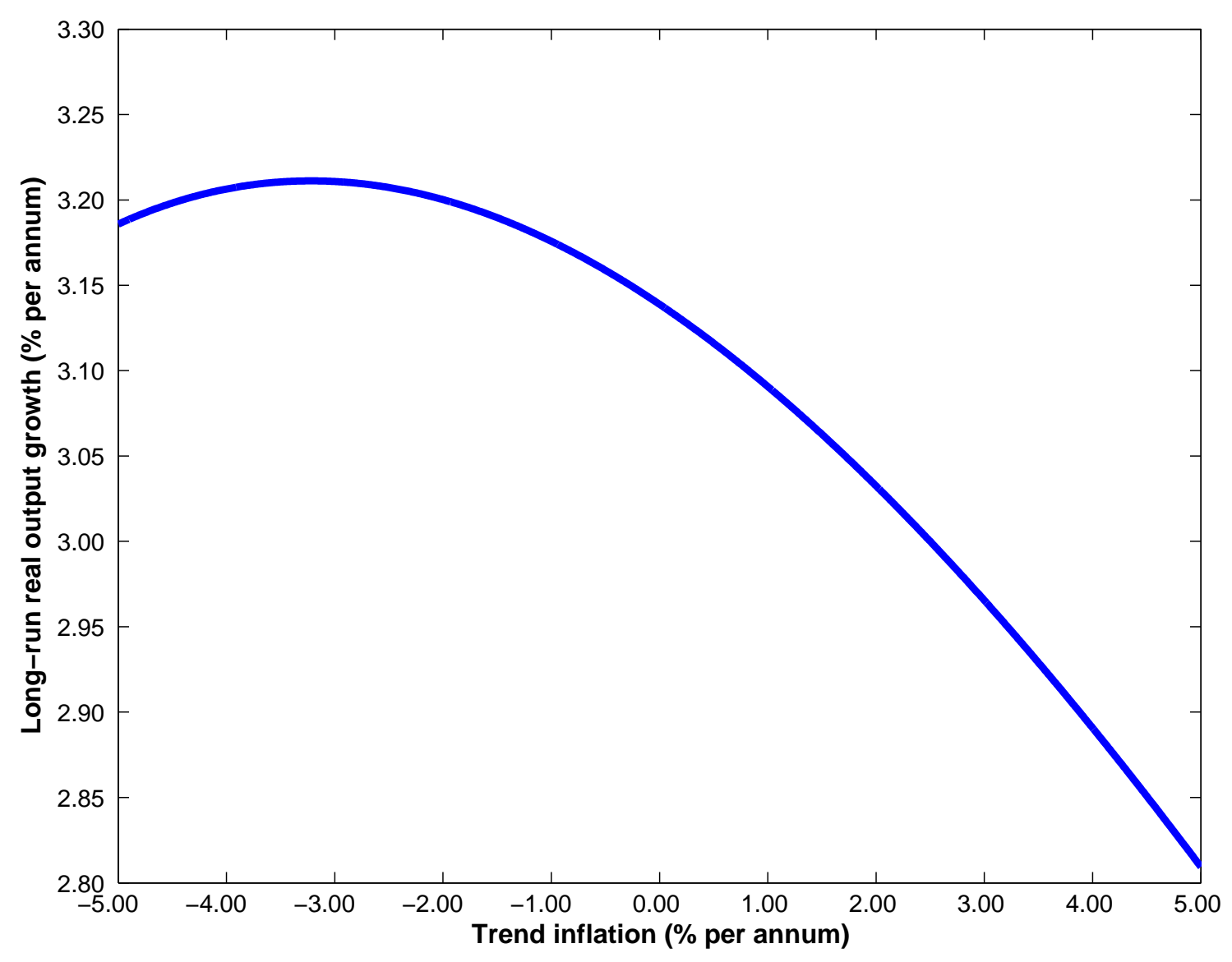


Figure 2: Direct, average mark-up, and labour supply effects versus inflation

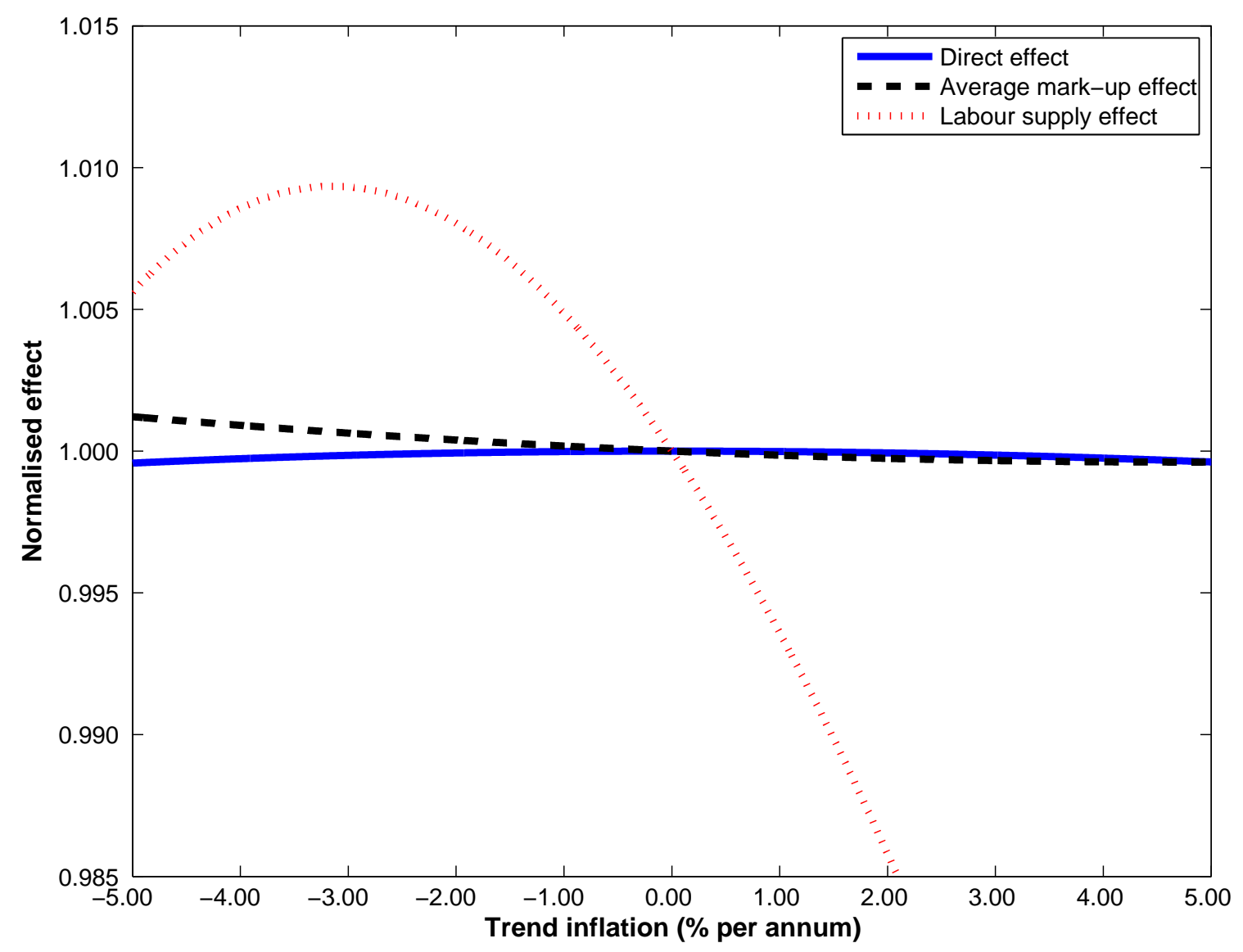


Figure 3: Welfare costs of inflation

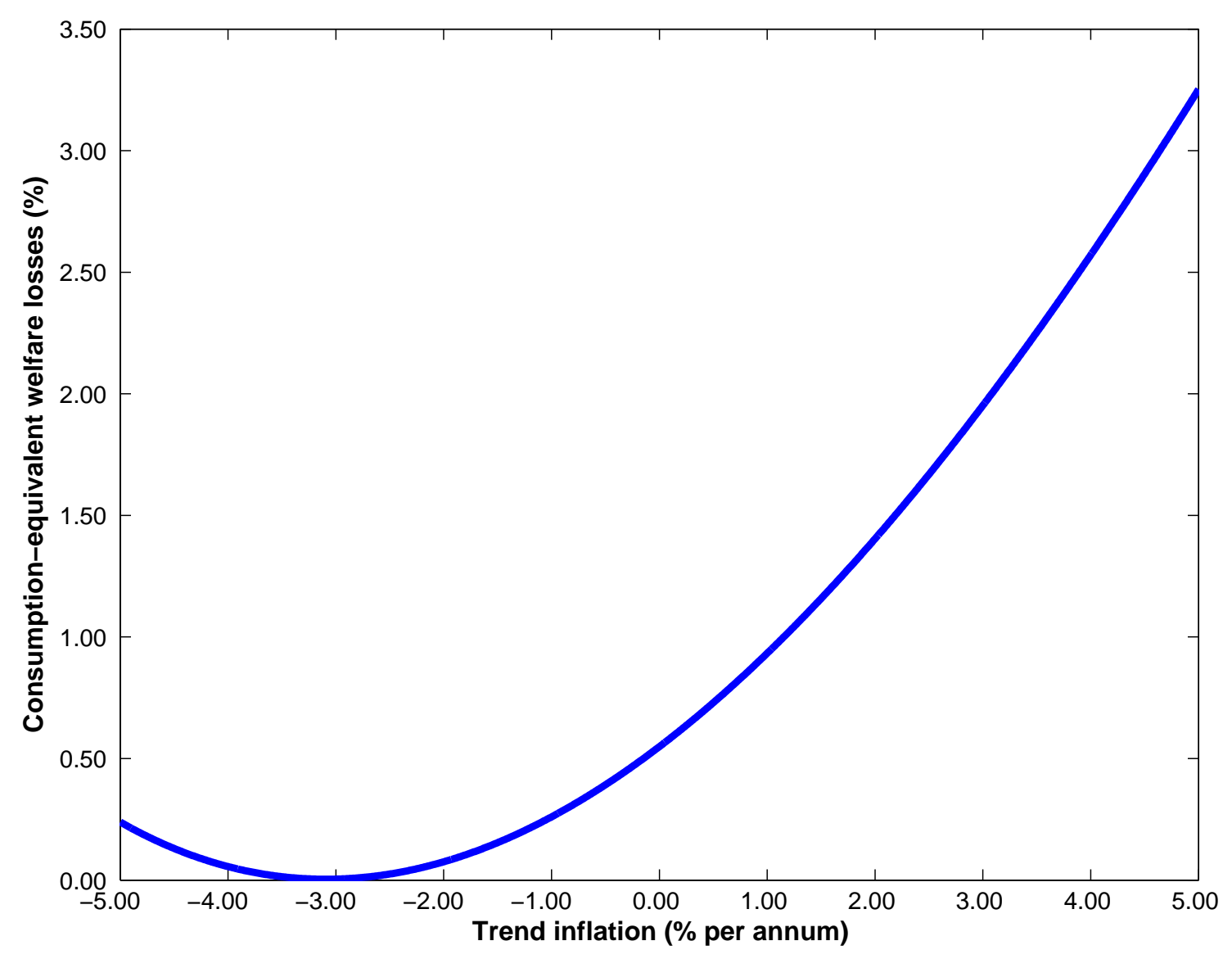


Figure 4: Decomposition of inflation's welfare costs

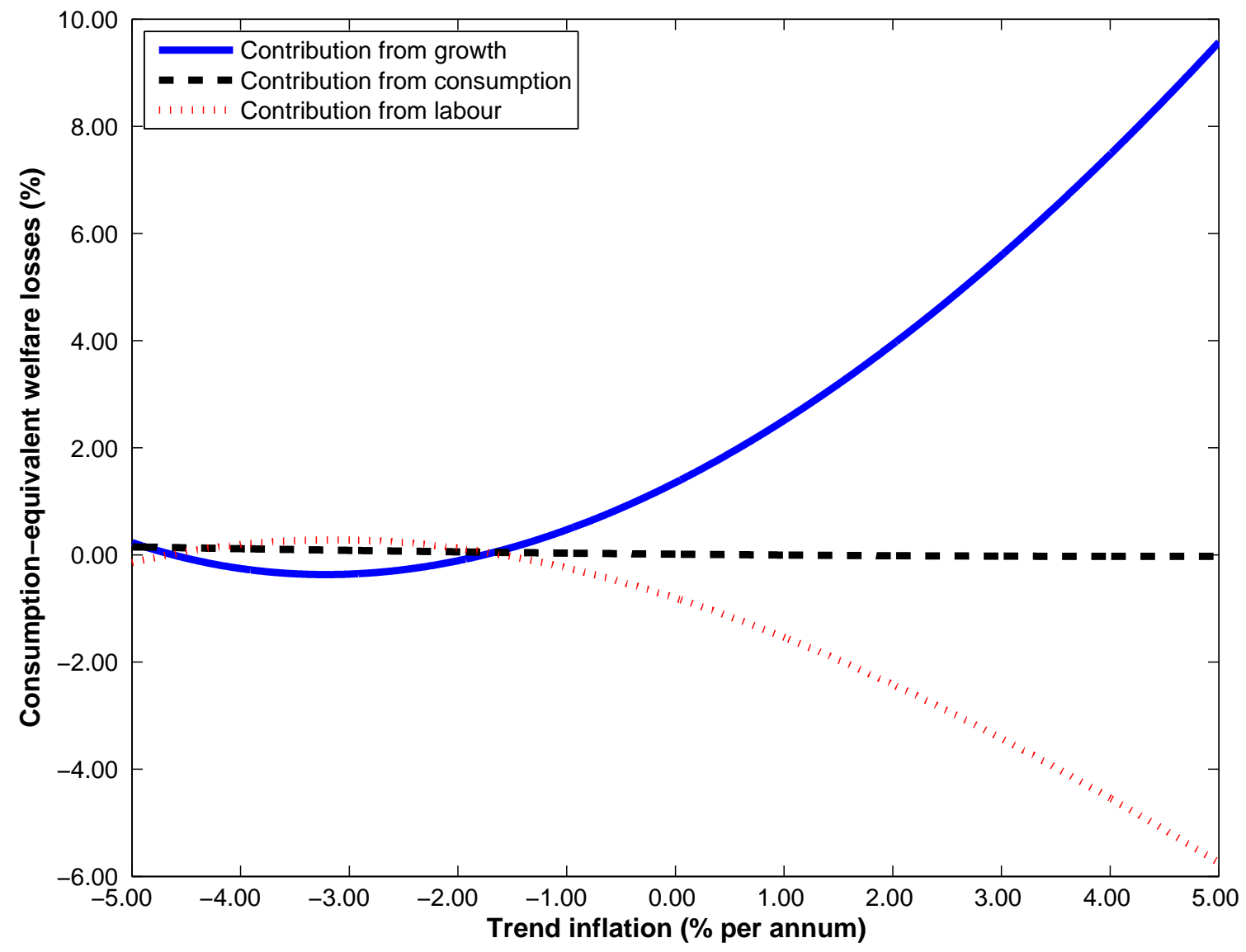

Table 1: Decomposition of inflation's welfare costs

\begin{tabular}{|l|ccccc|}
\hline & \multicolumn{4}{|c|}{ Consumption-equivalent welfare losses (\%) } \\
& $-2 \%$ inf'n & $0 \%$ & $2 \%$ & $5 \%$ & $10 \%$ \\
\hline Contribution from growth & 0.05 & 1.82 & 4.95 & 11.75 & 27.23 \\
Contribution from consumption & 0.06 & 0.02 & -0.00 & -0.00 & 0.07 \\
Contribution from labour & 0.04 & -0.78 & -2.22 & -5.16 & -11.04 \\
\hline
\end{tabular}


Figure 5: Sensitivity analysis: wage and price rigidity
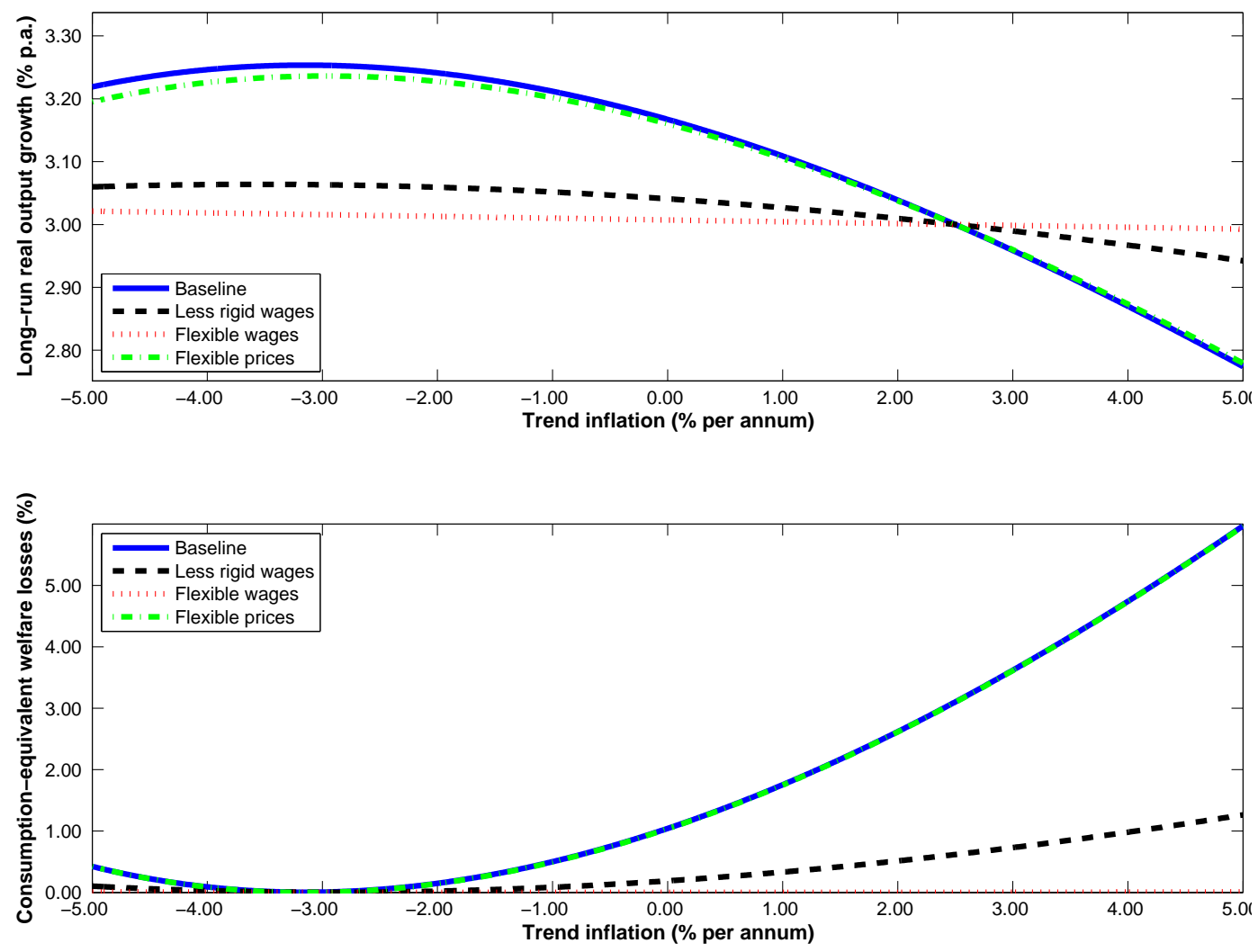
Figure 6: Sensitivity analysis: other parameters
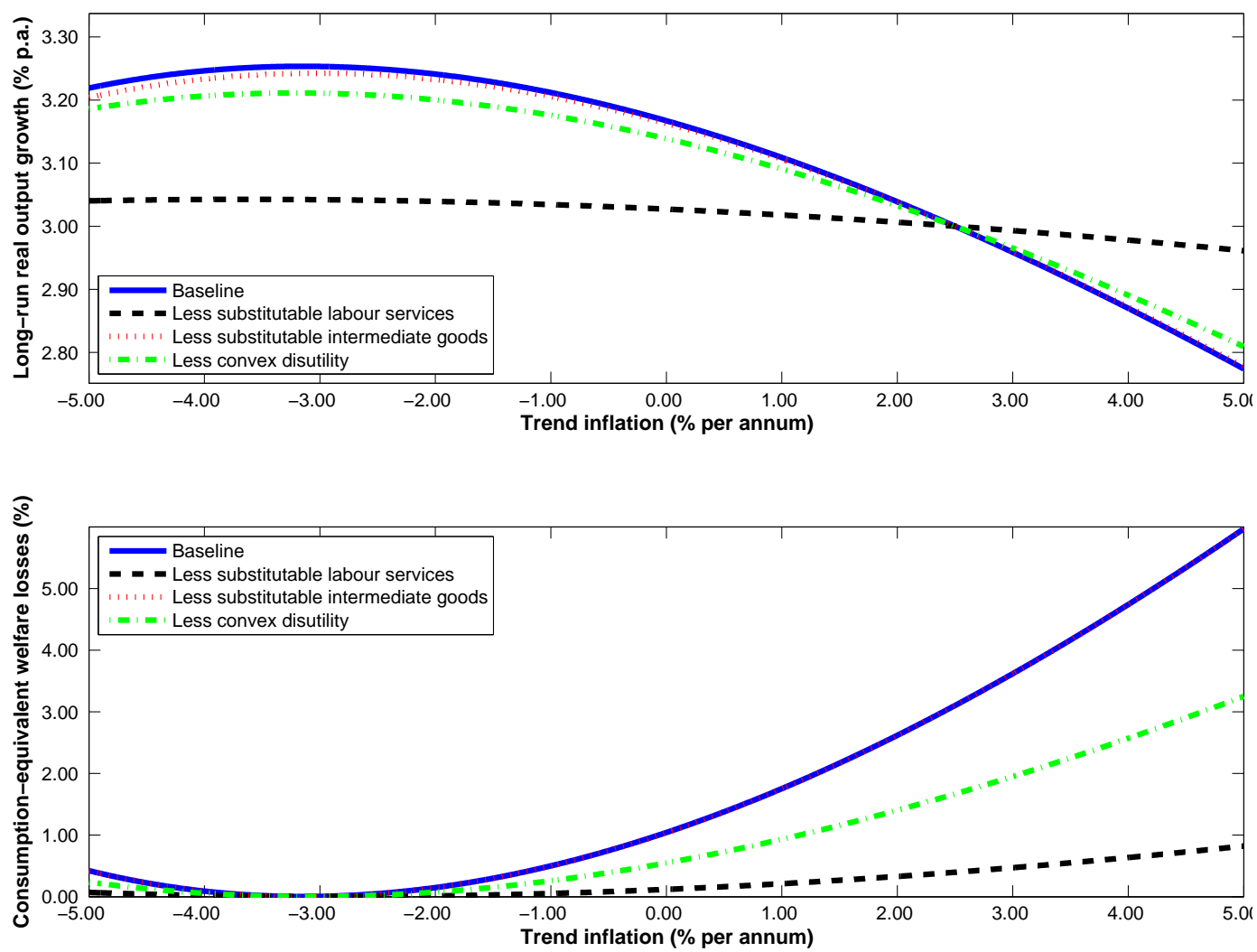